\title{
Conservative Endodontic Treatment of Type III Dens Invaginatus : Case Report
}

\author{
Wansun Jo, Nanyoung Lee, Sangho Lee \\ Department of Pediatric Dentistry, College of Dentistry, Chosun University
}

\section{Abstract}

Dens invaginatus is a developmental anomaly resulting from an infolding of the enamel organ into the dental papilla prior to calcification of the dental tissue.

Clinical and radiographic presentation of dens invaginatus shows a lot of variation. The classification proposed by Oehlers(1957) is most commonly used among classifications of dens invaginatus.

Several treatments have been suggested to treat Type III dens invaginatus where the pulp remains healthy but the invagination is associated with a periodontitis. The top priority objective is to preserve pulp as sound as possible. Thus, if there is no definite evidence of pulpal disease, the conservative access which treat invagination as distinct from the pulp is necessary.

But, Endodontic treatment of Type $\mathbb{I I}$ dens invaginatus has the particular problems associated with achieving adequate chemomechanical debridement of the root canal system and invagination, predictable length control and consistent filling.

In this case report, the endodontic treatment limited within invagination was performed for treatment of Type III dens invaginatus, and filling with Mineral Trioxide Aggregate(MTA) resulted in good prognosis.

Key words : Dens Invaginatus, Endodontic Treatment, Mineral Trioxide Aggregate(MTA)

\section{I. 서 론}

치내치는 치아조직의 석회화기 이전에 법랑기의 이상으로 인 해 치관내로 함입부가 생기는 치아의 발육성 이상으로 ${ }^{1.2}$, 주로 상악 전치부에 발생하며 그 중에서도 상악 측절치에 호발한다 ${ }^{3)}$.

발생원인은 아직 명확하지 않으나, 1937년 Rushton)은 발 생학 적으로 자극과 분화, 발육이 진행되는 동안 법랑기 세포의 성장이 치유두 안으로 일어났기 때문이라고 하였다. 1943년 Atkinson ${ }^{5}$ 은 치배가 발육하는 동안 가해지는 외적인 힘에 의 한 것이라고 제안하였으며, 이러한 힘은 인접한 치아로부터 올 수 있고, 다른 외적인 힘 즉, 외상이나 감염 또한 원인이 될 수 있다고 하였다. 또한, 최근에는 치내치에 유전성 소인이 있다는
여러 보고들이 설득력을 얻고 있다하. 치내치의 유병률은 $0.3 \sim 10 \%$ 로 매우 다양하게 보고되고 있으며, 이는 식별기준의 모호함이나 진단학적 어려움 때문일 것으로 생각된닥.

치내치는 함입부가 세균 침입의 통로가 되고, 치수강과 직접 적으로 또는 결함이 있는 얇은 법랑질과 상아질을 통해 간접적 으로 소통되므로, 치수괴사나 치근단 치주염으로 인한 치수질 환의 위험성이 증가한다 ${ }^{8)}$. 특히 Oehlers의 분류 중 Type III 병소는 치수질환을 동반하지 않은 치근단 치주염의 원인이 될 수 있다8).

이러한 치내치의 처치법으로는 함입의 예방적 봉쇄와 충전, 근관 치료, 치근단 수술, 의도적 재식술, 발치 등을 포함한 다양 한 접근법이 보고되어 왔다2.9.10). 이미 치수가 감염되어 임상 증 
상을 보이거나 방사선 사진상으로 치근단 병소를 보일 때는 일 차적으로 근관치료를 시행하여야 한달. 치수는 건강하게 남아 있고 함입 주위 치주염만 존재하는 경우는 치수의 생활력 보존 이 가장 우선시 되어야 하므로, 함입부를 치근과 별개로 치료할 수 있도록 해야 한다 ${ }^{11}$. 그러나 감염된 함입이 방사선 사진상 뚜 렷하게 분리되어 있고, 건전한 치수강과 따로 치료가 가능하더 라도, 근관과 함입 사이의 미세한 소통(pulpal communication) 가능성을 완전히 배제할 수 없으며, 특히, Type III 치내치의 경우, 함입에 법랑질 벽의 존재, 다양한 기형 형태, 정확한 치근 단의 부재 등으로 인해 완전한 충전이 매우 어렵다 ${ }^{11}$.

Mineral Trioxide Aggregate(MTA)는 치근단 충전 재료로 써 폭넓게 연구되어 왔으며 ${ }^{12)}, \mathrm{MTA}$ 의 좋은 물리적 성질과 치 수반응, 조직재생을 자극하는 능력 등을 고려했을 때, 이와 같 은 상황에서 선택할 수 있는 재료 중 하나로 여겨진다 ${ }^{11}$.

본 증례는 치근단 치주염을 보이는 Type III 치내치의 치료 에 함입부에만 제한된 보존적 근관치료 및 $\mathrm{MTA}$ 를 이용한 폐쇄 를 통해 양호한 결과를 얻었기에 보고하는 바이다.

\section{II. 증 례}

12 세 여아가 기형치가 있다는 주소로 조선대학교 치과병원 소아치과에 의뢰되었다. 임상 구강 검사상 상악 좌측 측절치 협 측 치은 부위에 배농을 위해 $\mathrm{Nu}$ Gauze(Trademark ${ }^{\odot}$, U.S.A.)가 삽입 된 상태였으며(Fig. 1A), 상악 좌측 측절치는 자발통의 병력은 없었고, 타진에 음성, 치아의 동요는 관찰되지 않았다. 치아는 우식없이 건전했으며, 설측면에 미약한 결절이 관찰 되었다. 별다른 의과적 병력은 없었다(Fig. 1B).

초진 시 파노라마 사진 상 치근단 부위에 큰 방사선 투과상 이 관찰되었다(Fig. $2 \mathrm{~A}$ ). 상악 좌측 측절치 치근단 방사선 사 진 상 치내치 형태를 보이며,가운데 명확한 함입부와 근단 측방
으로는 방사선 투과성 병소가 관찰된다(Fig. 2B). 임상검사와 방사선 사진 판독을 통해 치내치로 진단하였고, Oehlers의 분 류 중 Type IIIA로 진단 하였다.

함입부를 근관과 따로 분리해서 치료하고, 치아의 생활력은 보존하는 방법으로 치료계획을 선택하였다. 이 후 증상이 개선 되지 않을 시 근관과 치수강을 포함한 전통적인 근관치료를 시 도하기로 하였다.

당일 누공부위 세척과 소독, 항생제 처방을 하였고, 다음날 함입부에 제한된 근관치료를 시작하였다. 방사선 사진 상 근관 치료용 파일(file)이 함입부와 병소를 관통하는 것을 확인 하였 고(Fig. 3A), 병소의 개통을 위해 H-file과 Gate Glliden bur 를 순차적으로 이용하여, 함입부의 충분한 확대와 세척을 시행 하였다(Fig. 3B). 이 후 환자는 첫 1개월 동안 3 7일 간격으 로 수용성의 수산화 칼슘 제제 $\left(\right.$ CalcipexII ${ }^{\circledR}$, Nippon Shilka Yakuhin Co.,Ltd, Japan)를 이용한 멸균과 세척이 시행되었 다. 근관내 삼출물의 감소가 관찰되었으며, 지용성의 수산화 칼 슘제제 (Vitapex ${ }^{\circledR}$, Neo Dental Chemical Products Co.,Ltd, Japan)를 충전한 뒤 1 개월 간격으로 경과 관찰 시 지속적으로 병소가 치유되는 양상을 보였다(Fig. 4).

술 후 4 개월째, 병소는 특별한 증상없이 치유된 양상이 관찰 되었으며, 함입부의 완전한 폐쇄를 위해 $\mathrm{MTA}$ (PRO ROOT ${ }^{\circledR}$ MTA, Dentsply, Germany)를 이용한 함입부의 충전을 계획 하였다. 소독된 dried paper point를 이용하여 근관 내 건조를 시행 한 후, MTA를 충전하였다. 소독된 amalgam carrier를 사용하여 충전하였으며, plugger및 paper point를 사용하여 응축하였다(Fig. 5A). 이 후 함입부위 충전 양상을 정확히 확 인하기위해 CT촬영을 시행하였다(Fig. 5B).

MTA 충전 후 6개월째, 방사선 사진 상 정상적인 치유양상이 관찰되었다(Fig. 6). 추후 정기적인 임상적, 방사선학적 검진이 요구된다.
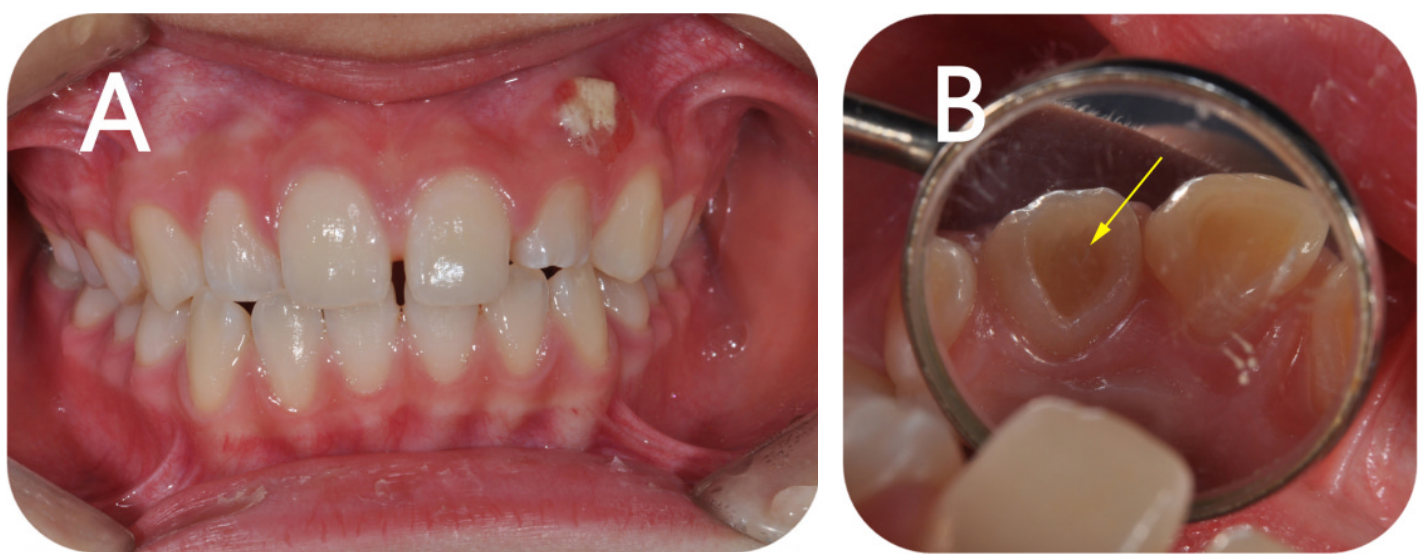

Fig. 1. (A) A fistula exists on the maxillary left buccal gingiva, and $\mathrm{Nu}$ Gauze(Trademark ${ }^{\odot}$, U.S.A.) was inserted for drainage at first visit, (B) The maxillary left lateral incisor is sound without caries, and the entrance of invagination was observed on the lingual surface. 


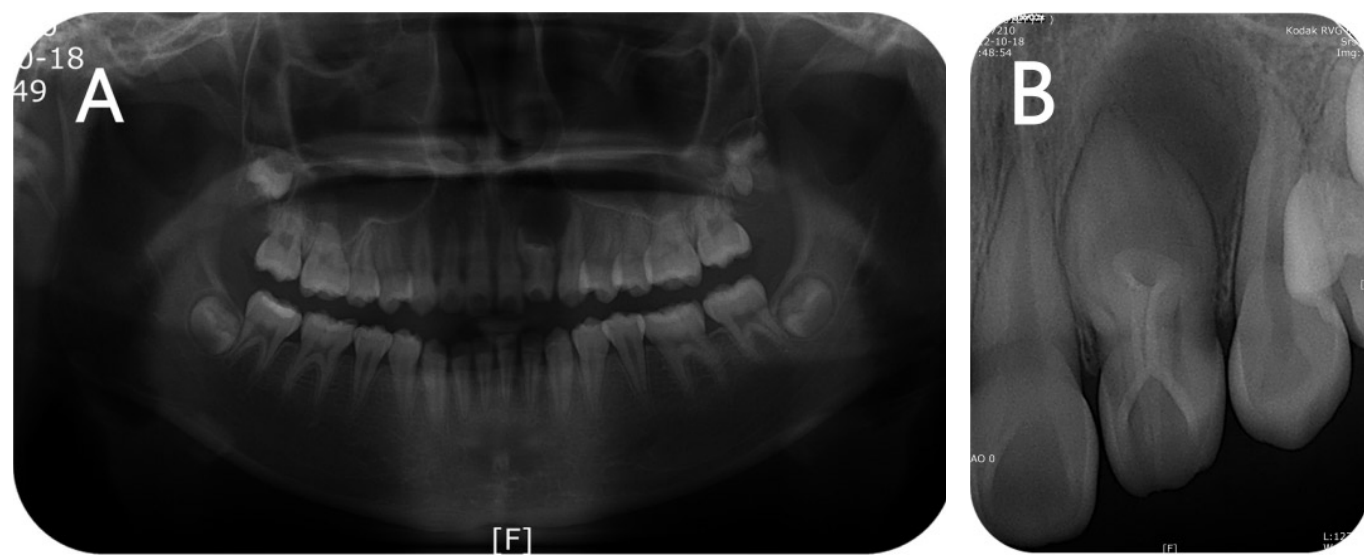

Fig. 2. Panoramic(A) and periapical(B) radiographs show apical radiolucency in periapical area of left maxillary lateral incisor.

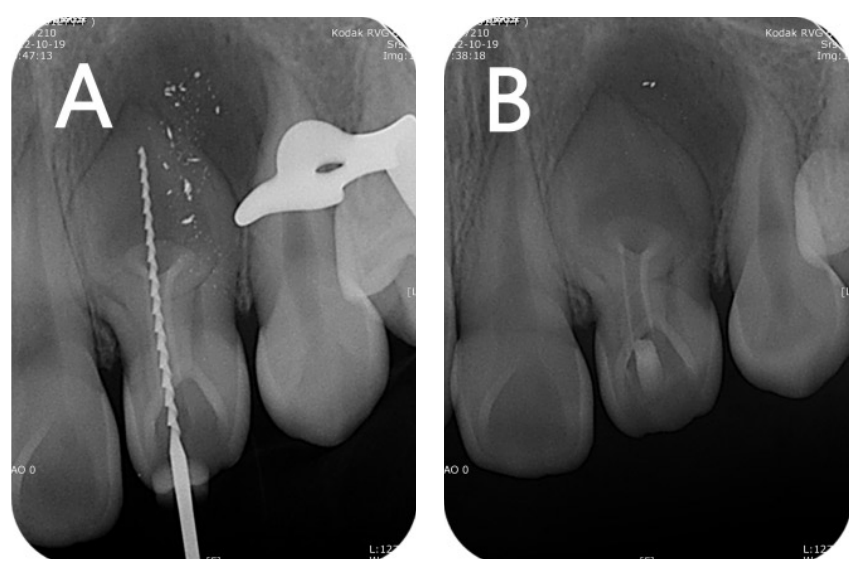

Fig. 3. (A) Opening the invagination was done using a file. It was confirmed that the invagination is connected with a lesion, (B) The invagination was temporarily filled after enlargement and irrigation.

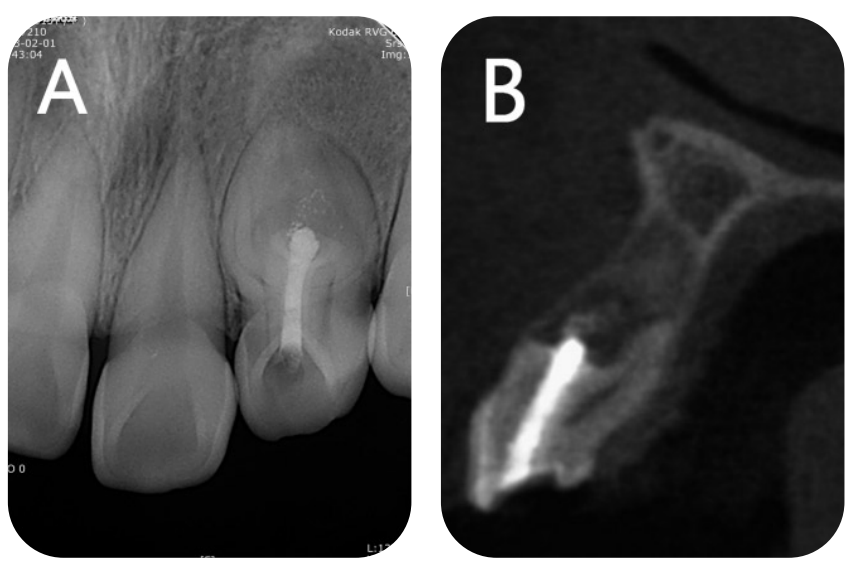

Fig. 5. (A) Radiographic view after 4 months, the invagination was permanently filled with MTA, (B) In the sagittal plane of CT image, it was observed that MTA sealed the invagination properly.

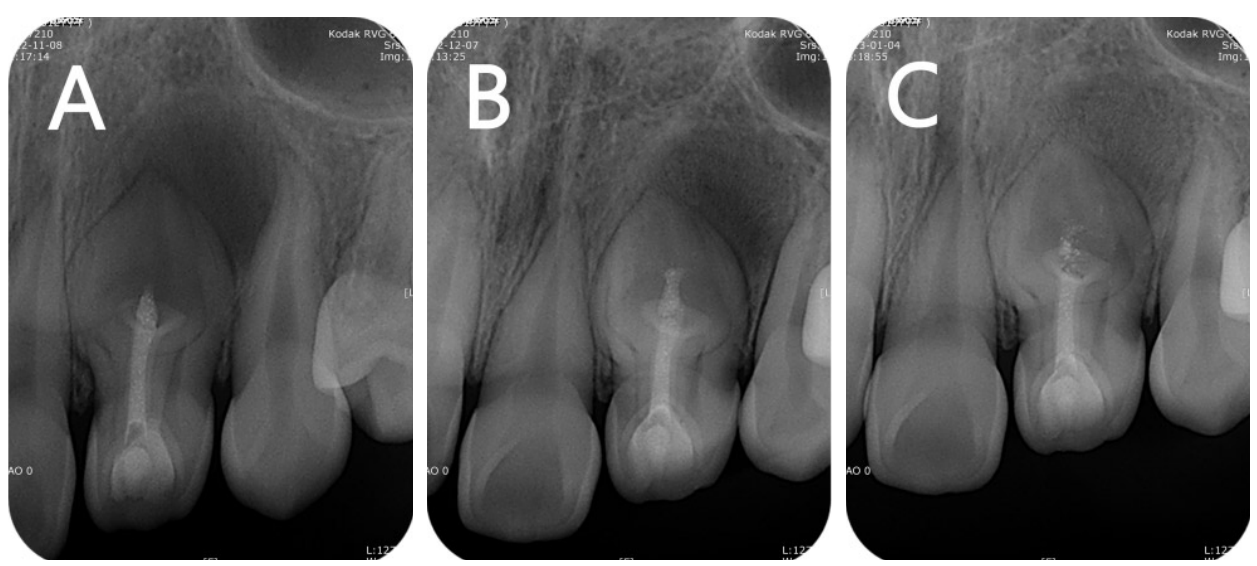

Fig. 4. (A) Radiographic views after 1 month, irrigation and calcium hydroxide paste replacement were performed every 3 - 7days, (B) After 2 months, it was observed that continuous healing of the lesion occurs, (C) After 3 months, it was observed that continuous healing of the lesion occurs.

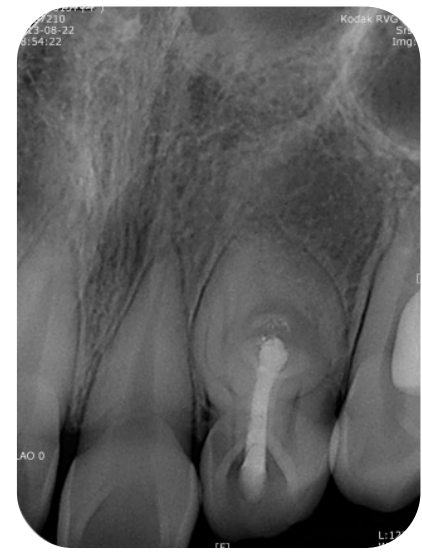

Fig. 6. Radiographic view at 4 months after the invagination was permanently filled with MTA. The lesion was gradually healed up. 


\section{III . 총괄 및 고찰}

치내치는 다른 비정상적인 발육이상보다 임상적으로 더 흔히 나타난다 ${ }^{7}$. 치내치가 비교적 일반적으로 접할 수 있는 발육이상 임에도 발견하지 못하고 지나치는 경우가 많은데, 이는 치내치 자체로는 어떠한 비정상적인 임상적 증상이 없기 때문이다. 치내 치는 대체로 방사선 사진 상에서 우연히 발견되는 경우가 많다.

그러나, 치내치는 비정상적인 형태로 인한 치수 감염과 변성 의 가능성이 높으므로, 1957 년 Oehlers ${ }^{14)}$ 는 치수 괴사와 근단 주위 염증을 예방하기 위해 조기 진단의 중요성을 강조하였다. 치내치를 분류하는 여러 방법 중 Oehlers가 제안한 분류법이 가장 널리 이용되는데 이는 함입이 치관에서부터 근단까지 방 사선학적으로 얼마나 멀리 존재하는지를 기준으로 다음과 같이 구분한다 ${ }^{7.13 .14)}$.

Type I: 함입이 최소이고, 법랑질에 둘러싸여있으며, 치아 치관에 의해 사방이 막혀있고, CEJ를 넘어가지 않는 상태.

Type II: 함입이 법랑질에 둘러싸여있으며 치수강까지 진 행되었지만 근관은 치주인대와 어떠한 연결 없이 남아있는 경우.

Type IIIA: 함입이 치근 사이로 존재하고 pseudo-foramen 을 통하여 측면으로 치주인대와 연결되어있다. 일반적으로 치 수와 연결되어 있지는 않고 치근 내에 평평하게 놓여있다.

Type IIIB: 함입이 치근 사이로 존재하고 치근단공 쪽에서 치주인대가 연결된다. 치수의 연결은 일반적으로 없다.

이러한 함입의 정도와 임상 증상에 따라 다양한 치료적 접근 이 가능하다 ${ }^{2}$. 함입이 치관에만 국한되어 있고, 치수 질환의 근 거가 없는 상황에서는, 방습조절이 되는대로 예방적 치료를 시 행해 주는 것이 바람직하다. 치면 열구 전색제나 유동성 레진으 로 함입의 입구를 효과적으로 봉쇄할 수 있다 ${ }^{11}$.

이미 치수가 감염되어 임상증상을 보이거나 방사선 사진 상 으로 치근단 병소를 보일 때는 근관치료를 시행하여야 한다 ${ }^{3)}$. 그러나 치수, 치근단 질환에 이환된 치내치는 비정상적인 형태 로 인해 근관치료가 매우 복잡하고 때로는 불가능하며8), 해부학 적 형태로 인하여 종종 발치를 시행해야 할 경우도 있달. 특 히, Type III 치내치의 근관 치료시, 근관과 함입의 충분한 잔 사제거, 재현가능한 근관장의 조절, 일관된 충전 등을 달성하기 어렵다 ${ }^{15,16)}$.

그러나 이러한 한계점에도 불구하고 Type III 치내치를 동반 한 치근단 병소를 근관치료를 통해 성공적으로 처치한 여러 보 고들이 있으며 ${ }^{17.18)}$, 함입부의 기계적인 잔사제거는 어렵지만, 물리 - 화학적 기구조작과 수산화 칼슘제제의 병용만으로도 다 른 수술적인 처치 없이 효과적이었다 ${ }^{19)}$.

이 증례에서는 함입부 병변을 처치하기 위해 환자에게 첫 1 개월간 3 7일 간격의 세척 및 수산화칼슘 제제의 교체를 시행 하였으며, 치근단 방사선 사진상 양호한 치유양상이 관찰되었 다(Fig. 4). 수산화칼슘 제제는 함입 근관에서 항균작용과, 조 직 용해 효과 그리고 삼출물의 조절을 위해 사용될 수 있다 ${ }^{20.211}$.
더욱이, 수산화칼슘 제제는 근단 주위의 $\mathrm{pH}$ 를 증가시키고, 치 유과정에 필요한 칼슘 이온을 제공함으로써 근단 병소의 치유 에 긍정적인 효과가 있다2).

그러나, 아무리 근관을 잘 확대하고 세척해 주어도 근관 내에 는 항상 염증조직이나 박테리아들이 남아있게 된다. 근관의 충 전이란 이렇게 남아있는 자극원들을 밀폐시킴으로써 더 이상 자극원으로서의 역할을 할 수 없게 만들어 주는 것을 의미한다 ${ }^{23)}$. Type III 치내치의 경우, 함입부에 법랑질 벽의 존재, 다양한 기형 형태, 정확한 치근단의 부재 등은 완전한 충전을 어렵게 만든다. 또한 함입부와 건전한 치수강 간의 소통(pulpal communication) 가능성 역시 배제 할 수 없다 ${ }^{11}$.

이 증례에서는 충전시의 이러한 문제점들을 해결하기 위해 근관충전재로 MTA를 사용하였다. MTA는 미세누출을 통한 세균의 침입을 방지하고, 치수 보호에 효과적이며, 수복물과 함 께 사용하여 치수의 생활력을 유지시킬 수 있다 ${ }^{24)}$. 이러한 생물 학적 특성들 덕분에 MTA는 치수복조, 치수절제술, 미성숙 영 구치의 치근단 역충전술, apical plug, 근관 폐쇄, 천공과 파절 의 수복등의 많은 임상과정에 적용되고 있다 ${ }^{24)}$. 본 증례에서는 $\mathrm{MTA}$ 를 함입부의 최종적인 충전 재료로 사용하였으며, 술 후 6 개월의 정기 검진에서 양호한 치유양상이 관찰되었다(Fig. 6).

추후 정기적인 임상적, 방사선학적 검진이 요구된다.

$$
\text { IV. 요 약 }
$$

치내치는 치수질환에 이환될 가능성이 높으며, 비정상적인 형태로 인해 근관치료에 많은 어려움이 존재한다. 그러므로 치 내치의 조기진단과 적절한 예방적 치료가 중요하다.

치내치에 비정상적인 임상증상이 발생했을 경우, 함입의 정 도와 증상에 따라 다양한 치료적 접근이 가능하다. 그러나 치수 는 건강하게 남아있고 함입 주위 치주염만 존재하는 경우, 치수 생활력을 보존하기 위해서는 함입부에 제한된 보존적인 근관치 료가 필요하다.

본 증례에서는 치근단 치주염을 보이는 Type III 치내치의 치료에 함입부에만 제한된 보존적 근관치료를 시행하였다. 감 염된 병변의 처치에 수산화 칼슘제제를 사용하였으며, 이 후 함 입부의 폐쇄를 위해 $\mathrm{MTA}$ 를 충전재로 사용하여 양호한 결과가 관찰되었다. MTA의 특성을 고려하였을 때, 이러한 처치 시 효 과적인 근관충전재로 사용할 수 있을 것으로 여겨진다.

\section{References}

1. Chen YH, Tseng CC, Harn WM : Dens invaginatus. Review of formation and morphology with 2 case reports. Oral Surg Oral Med Oral Pathol Oral Radiol Endod, 86:347-52, 1998.

2. De Sousa SM, Bramante CM : Dens invaginatus: treatment choices. Endod Dent Traumatol, 14:1528, 1998. 
3. Korean academy of pediatric dentistry : Pediatric dentistry, 4th ed. Shinhung International, Inc, Seoul, 112-113, 2007.

4. Rushton MA : A collection of dilated composite odontomas. British Dental Journal, 63:65-85, 1937.

5. Atkinson SR : The permanent maxillary lateral incisor. American Journal of Orthodontics, 29:68598, 1943.

6. Hosey MT, Bedi R : Multiple dens invaginatus in two brothers. Endod Dent Traumatol, 12:44-7. 1996.

7. Alani A, Bishop K : Densinvaginatus. Part 1:classification, prevalence, aetiology. Int Endod J, 41:11231136, 2008.

8. Tomoatsu Kaneko, Hitoshi Sakaue, Takashi Okiji, et al. : Clinical management of dens invaginatus in a maxillary lateral incisor with the aid of conebeam computed tomography-a case report. Dent Traumatol, 27:478-483, 2011.

9. Hata G, Toda $\mathrm{T}$ : Treatment of dens invaginatus by endodontic therapy, apicocurettage, and retrofilling. J Endod, 13:469-72, 1987.

10. De Martin AS, Da Silveira Bueno CE, Fernandes de Magalhaes Silveira C, et al. : Endodontic treatment of dens invaginatus with a periradicular lesion: case report. Aust Endod J, 31:123-5, 2005.

11. K. Bishop, A. Alani : Dens invaginatus. Part 2: clinical, radiographic features and management options. Int Endod J, 41:1137-1154, 2008.

12. Chong BS, Pitt Ford TR, Hudson MB : A prospective clinical study of mineral trioxide aggregate and IRM when used as root-end filling materials in endodontic surgery. Int Endod J, 36:520-6, 2003.

13. Zengin AZ, SumerAP, Celenk P : Double dens invaginatus : Report of Three Cases. Eur $J$ Dent, 3:67-70, 2009.

14. Oehlers FAC : Dens invaginatus. Part I: variations of the invagination process and association with anterior crown forms. Oral Surg Oral Med Oral Pathol, 10:1204-1218, 1957.

15. Tagger M : Nonsurgical endodontic therapy of tooth invagination. Oral Surg Oral Med Oral Pathol, 43: 124-9, 1977.

16. Holtzman L, Lezion R : Endodontic treatment of maxillary canine with dens invaginatus and immature root. Oral Surg Oral Med Oral Pathol Oral Radiol Endod, 82:452-5, 1996.

17. Szajkis S, Kaufman AY : Root invagination treatment: a conservative approach in endodontics. $J$ Endod, 19:576-8, 1993.

18. Schwarts SA, Schindler WG : Management of a maxillary canine with dens invaginatus and a vital pulp. J Endod, 22:493-6, 1996.

19. Saeed Moradi, Zakyeh Donyavi, Mohammad Esmaealzade : Non-surgical root canal treatment of dens invaginatus 3 in a maxillary lateral incisor. Iranian Endod J, 3:38-41, 2008.

20. Bystrom A, Claeson R, Sundquist G : The antibacterial effect of camphorated paramonochlorophenol, camphorated phenol and calcium hydroxide in the treatment of infected root canals. Endod Dent Traumatol, 170-5, 1985.

21. Sathorn C, Parashos P, Messer H : Antibacterial efficacy of calcium hydroxide intracanal dressing: a systematic review and meta-analysis. Int Endod J, 40:2-10, 2007.

22. Farhad A, Mohammadi Z : Calcium hydroxide : a review. Int Dent J, 55:293-301, 2005.

23. Seung-Jong Lee, et al. : Atlas of Endodontic Practice, 3rd ed. Shinhung International, Inc, Seoul, 136-171, 2007

24. Arathi Rao, Ashwini Rao, Ramya Shenoy : Mineral Trioxide aggregate-A Review. J Clin Pediatr Dent, 34:1-8, 2009. 
국문초록

\title{
Type III 치내치의 보존적 근관치료 : 증례보고
}

\author{
조완선 · 이난영 · 이상호
}

조선대학교 치의학전문대학원 소아치과학교실

치내치란 치아 조직의 석회화가 일어나기 이전에 법랑기가 치유두 내로 함입되어 나타나는 발육성 이상을 말한다.

치내치는 임상적, 방사선학적으로 다양한 변이를 나타내며, 치내치의 여러 분류법 중 Oehlers(1957)가 제안한 분류법이 가장 널리 이용되고 있다.

치수는 건강한 채로 남아 있으나 함입부가 치주염과 연관된 Type III 병소를 치료하는데 다양한 술식들이 설명되어져왔다. 가장 우선시 되어야 하는 목표는 가능하다면 치수를 건전하게 보존하는 것이며, 치수질환의 명백한 증거가 없다면, 함입부를 치근과 별개로 치료하는 보존적인 접근법이 필요하다. 그러나, Type III 치내치의 근관치료는 근관과 함입의 충분한 잔사제 거, 재현가능한 근관장의 조절, 일관된 충전등을 충분히 달성하기 어렵다는 문제점이 있다.

본 증례는 치근단 병소를 보이는 Type III 치내치의 치료에 함입부에만 제한된 보존적 근관치료 및 Mineral Trioxide Aggregate(MTA)를 이용한 폐쇄를 통해 양호한 결과를 얻었기에 보고하는 바이다.

주요어: 치내치, 근관치료, Mineral Trioxide Aggregate(MTA) 